Howe, K. (1998). The Interpretive Turn and the New Debate in Education. Educational Researcher, 27(8), 13-21. This work may be downloaded only. It may not be copied or used for any purpose other than scholarship. If you wish to make copies or use it for a non-scholarly purpose, please contact AERA directly.

\title{
The Interpretive Turn and the New Debate in Education
}

\author{
KENNETH R. HOWE
}

\begin{abstract}
Over the last several decades, positivist-behaviorist approaches to social and educational research have been on the decline, whereas interpretivist approaches have been on the rise. As a result of this "interpretive turn," the old debate between positivism and interpretivism (and central to the quantitative-qualitative debate) has diminished in intensity only to be replaced by a new debate within interpretivism. This article characterizes the new debate in terms of postmodernists - who would abandon_the-emancipatory.project of modernity as fatally flawed - versus transformationistswho would modify this project and endeavor to see it through. Among the conclusions advanced is that the differences between these two general perspectives tend to be overdrawn, particularly when philosophical avowals are measured against the requirements of practice.
\end{abstract}

Educational Researcher, Vol. 27, No. 8, pp. 13-20

$\mathbf{R}$ abinow and Sullivan (1979)_coined the phrase the "interpretive turn" to describe the epistemological shift under way in the social sciences in the mid to late 20 th century away from positivism and toward interpretivism. That Rabinow is an anthropologist and Sullivan is a philosopher symbolizes the merging of the social sciences and the humanities associated with this development. Charles Taylor addresses the point explicitly in his seminal "Interpretation and the Sciences of Man" (1987), where he rejects the view that there can be any scientifically neutral, impersonal language (a central tenet of positivism) with which to describe and interpret human activities. Rather, he says, "we have to think of man [ [sic] as a self-interpreting animal. ... [T] here is no such thing as the structure of meanings for him independently of his interpretation of them" (p. 46, italics added). (See also Taylor, 1991, 1995.) This general perspective provides the epistemological underpinning for the current emphases in the social sciences and humanities on the cultural embeddedness of human identities and interests and-on including hitherto marginalized or excluded voices in our various conversations.

If the interpretive turn has not completely won out in educational theory, if is certainly in ascendancy. And this development has prompted a new debate that is highly germane to educational research but that also has far-reaching consequences for curriculum, pedagogy, and the political mission of education. In this article, I portray and-evaluate this debate in terms of three broad issues: epistemology,politics, and the ôntology of the self. In each case, I compare two versions of interpretivism: what I call the postmodernist and the transformationist perspectives (to be elaborated below). Along the way, I consisfently side with-the-tranfor- mationists. Nonetheless, I suggest in the end that the differences between these two general perspectives tend to be overblown.

Developing this analysis will require negotiating some pretty treacherous conceptual ground. For one of the things that characterizes the new debate is that the terms in which it is couched-interpretivism, postmodernism, constructivism, deconstructionism, and so forth-are not only employed in different ways by different people. The terms are also sometimes quite explicitly contested. There is no way I can sort through all of the conceptual ambiguity and controversy the new debate engenders in this article. So l'll do the next best thing: acknowledge the difficulty and specify the meanings I attach to its central terms. I'll provide some clarifications here at the outset and some others as my analysis unfolds.

By interpretivism, I mean the broad epistemological-view sketched above associated with-the "interpretive turn" and not a particular research method or set of research methods. Although interpretivism is more closely linked (both historically and conceptually) with qualitative than quantitative methods, the general interpretivist perspective need not jettison quantitative methōds. The idea that social and educational researchers are precluded from_employing both qualitative and quantitative methods is a thesis of the old quantitative-qualitative debate that has now become passé (Howe, 1992; Howe \& Eisenhart, 1990), something with which even those who otherwise have been at odds with my views agree (e.g., Smith \& Hëshusius, 1986).

By postmodernism, 1 mean a certain perspective on the interpretive-turn: that the political philosophy and epistemology dominantever approximately the last three and a half centuries, since the Enlightenment, are at a dead end, the perspective that, as David Lyon (1994) puts it, the emancipatory_project of modernity has "exhausted itself." The task of social research and philosophy is to deconstruct, denormalize, dismantle, and so forth modernity's still quite powerful presence.

By transformationism, I mean another perspective on the interpretive turn: that although significantly flawed, much of the emancipatory project of modernity can beand ought to begpreserved. The task of social research and philosophy is to see this project through.

KENNETH R. HOWE is a professor in the School of Education at the University of Colorado at Boulder, Boulder, CO 80309-0249. He specializes in the philosophy of education. 
As I said above, my analysis requires negotiating some treacherous conceptual ground, and the postmodernisttransformationist distinction presents some special problems in this vein. A significant lack_of_agreement exists about who qualifies as a postmodernist. Derrida, Foucault, and Lyotard are on most lists; Rorty-and Wittgenstein are on some (e.g., Beck, 1994); some even include Dewey (e.g., Doll, 1993). To make matters worse, some of those who often turn up on these lists explicitly disclaim the description-Foucault_is_a prime_example of this-and others who turn up are-more often seen as alternatives to the postmodernist stance-Dewey is a prime_example_of this. Still I can find no better term than postmodernism to represent one side-of the new debate. The term is ubiquitous, many thinkers line up against it (or what they think it is), and finally, the last thing needed is yet another term to further confuse things.

Transformationist presents similar problems for it collapses into one category critical theorists (e.g., Jurgen Habermas), pragmatists (e.g., me), and certain feminists (e.g., Nancy Frazer). (Frazer, 1995, suggests the term nee-

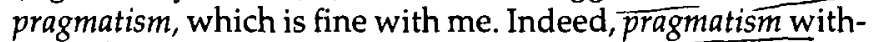
out the neo is fine with me. But I want to avoid introducing yet more complexity.) Despite their differences; which can be vast, the thinkers I call transformationists are united in their opposition to postmodernism - or at least to a strong (Benhabib, 1995) version of it that they accuse of being radically relativistic, hyperskeptical, and nihilistic.

The postmodernist-versus-transformation framework has the virtue of setting the new debate into sharp relief and capturing several general themes that are currently animating important controversies within educational theory and practice. I have already announced my allegiance to the transformationist perspective, so in this sense, my analysis will not be entirely objective. On the other hand, I will suggest toward the end that, in education at least, postmodernists and transformationists are-not.(or need not be) at loggerheads, that each is committed both-to.criticizing and dismantling_(deconstructing,_if_you_will)_unjust and undemocratic educational practices and to transforming them.

\section{Epistemology}

Interpretixists share a constructivist epistemology, broadly construed-Genstructivists in this sense may be set over and against classical empiricists and their offspring, the positivists. They uniformly reject what Dewey called the "spectator view" of knowledge-the view that knowledge is built up piece by piece by accumulation of an ever-growing and increasingly complex arrangement of passively received, neutral observations. Instead, knowledge, particularly in social research, must be seen as actively constructed and, accordingly, as not neutral but culturally and historically-contingent, laden with moral and political values, and serving certain interests and purposes.

But this creates a formidable problem for interpretivists: Is knowledge (or what passes for it) merely_a culturalhistorical artifact? Is it merely a collection of moral and political values? Does it merely serve certain interests and purposes? Postmodernists and transformationists offer a different answer to these questions.

Postmodernists seem to answer "yes"-or at least seem to have no grounds for answering "no." Consider Lyotard's definition of postmodernism: "I define Lostmodern as in- credulity_toward metanarratives" (1987, p. 74). Briefly, a metanarrative is a grand legitimating story, one important feature of which is its abstraction from time, place, and culture. Metanarratives include grand epistemological stories such as the inevitable progress of science and grand political stories such as Marxism and liberalism.

The Marxist and liberal traditions each embrace the goal of the emancipation of humankind, and postmodernists are highly suspicious of them for precisely this reason. Because the goal of emancipation incorporates a peculiarly Western epistemology, pursuing it serves, as Lyotard says, to terrorize peoples who had no part in writing it. It is, after all, a time-, place-, and culture-bound story of human knowledge, and accordingly, is a very bad fit for many sociocultural groups. Worse, by presupposing certain conceptions of knowledge and rationality, it masks the manner in which modern Western societies oppress the many Others that exist within them and is thus a bad story for Western societies themselves. In the end, it blunts rather than fosters emancipation (e.g., Ellsworth, 1992).

Michel Foucault (1987) shares Lyotard's attitude toward metanarratives and would supplant them with what he calls genealogy. Foucault's method is to unearth (he has also employed the related notion of archeology) the historicalantecedents that have given rise to the rationalization of modern institutions. For Foucault, rationality is irremediably historical_and_contingent, and there can be no extrahistorical touchstones-metanarratives - of the kind philosophers have sought since Plato. Related to this, knowledge and power are inextricably wedded in "regimes of truth" that function to normalize persons-that is, to rendẽr them acquiescent and useful vis-à-vis the institutions of modern society.

This description of the postmodernist incredulity toward metanarratives should be sufficient to elucidate the basis for the general criticism that so routinely leaps to the minds of critics: that postmodernism is hopelessly relativistic and self-defeating, that it cannot, if consistently held, justify any knowledge claims whatsoever. For if all knowledge claims are thoroughly context bound and are merely masks for interests and power, are not any postmodernists who might advance themselves also possessed of these features? Is not knowledge, then, just an illusion? And are not radical relativism, nihilism, and moral-political paralysis the unavoidable implications?

To be sure, postmodernists do not embrace these implications. Foucault (1987) seeks through his forms of analysis to displace seeming self-evidentness about normalcy and the practices that go with it, and he has a clear-albeit open-ended-political project here. Lyotard (1987) embraces the concept of justice but would replace the modernist conception that relies on consensus (homology) with a postmodernist conception that facilitates the expression of difference (paralogy).

Transformationists believe these kinds of moves simply won't work. Because of their epistemological commitments, postmodernists either they have no way of getting their project off the ground in the first place or leave political practice so uncharted as to have no destination. Transformationists join postmodernists in rejecting the traditional philosophical quest for ultimate epistemological touchstones that transcend contingent human experience. But "overcoming epistemology," to use Charles Taylor's 
phrase (1995, chapter 1), does not entail what they see the postmodernists doing: abandoning knowledge and rationality as illusory. Transformationists see their task as working out defensible conceptions of knowledge and rationality that have contingent human experience as their basis. In this way, the transformationist project is continuous with the emancipatory project of modernity. The postmodernist project, by contrast, is discontinuous. It seeks a fundamental break-or rupture.

As I said before, among transformationists may be counted pragmatists, critical theorists, and (certain) feminists. ${ }^{1}$ Thomas Kuhn $(1970,1977)$ perhaps provides the best general description of the transformationist epistemological view when he likens it to Darwinian evolution. In short, there exists no acontextualized criterion of knowledge toward which science must move. Instead, scientific theories are supported to the extent that they better handle the problematic than their competitors. A sort of bootstrapping characterizes scientific knowledge. Criteria for making these judgments exist, but they may not be mechanically applied, have no ultimate foundation, and are not settled once and for all.

Kuhn's emphasis, of course, is scientific paradigms, and the contours of his thesis are widely known if not also widely accepted. Of more interest for my purposes here, however, is the less familiar and less discussed (in the education literature at least) issue of moral epistemology.

Michael Walzer distinguishes two ways of doing moral philosophy:

One way to begin the philosophical enterprise is to walk out of the cave, leave the city, climb the mountain, fashion for oneself ... an objective and universal standpoint.... But I mean to stay in the cave, in the city, on the ground. Another way of doing philosophy is to interpret to one's fellow citizens the world of meanings we share. Justice and equality can conceivably be worked out as philosophical artifacts, but a just or an egalitarian society cannot. If such a society isn't already there-hidden, as it were, in our concepts and categories-we will never know it correctly or realize it in fact. $(1983$, p. xiv)

Charles Taylor (1995, chapter 3) employs a distinction similar to Walzer's by identifying two models of practical reason: apodictic and ad hominem. The apodictic model requires that there be (a) some independent criterion, uncontaminated by any particular system of beliefs, values, and dispositions, against which to check the claims of practical reason and (b) some fail-safe procedure by which to determine whether the criterion is met. But this sets an impossible standard. (Even science can't meet it if Kuhn is right, and Taylor explicitly draws a parallel.) Because it cannot be met, practical reason-the reasoning that applies in morals and politics-collapses into subjectivism and nihilism, accompanied by the belief that moral and political claims are always and everywhere based on mere prejudice or bias.

But this follows only if there is no alternative way to construe practical reason, and Taylor believes there is: the ad hominem model. Taylor begins with a fact about practical reason that $I$, too, have noticed. Moral claims are often much more complex than they first appear. They almost always may be qualified when challenged with some form of "special pleading" that excuses or redefines what is being advocated and what it implies. Consider the charge that the back-to-basics movement, combined with high-stakes test- ing, shows a calloused disregard for diversity and threatens to further disadvantage groups that have historically fared poorly in schools, and consider the "special pleading" exemplified in proponents of these kinds of policies: "No, you are wrong. We really want help the disadvantaged. Rigor and accountability are the best way to do this." Even outrageous moral claims exhibit this pattern, as Taylor observes in the case of the practical reasoning of Nazis:

[Nazis] never attack the ban on murder of conspecifics frontally. They are always full of special pleading: for instance, that their targets are not of the same species, or that they have committed truly terrible crimes which call for retaliation, or that they present a mortal danger to others. (1995, p. 35)

Taylor uses the "special pleading" phenomenon and the underlying agreement it implies as the basis for the following picture of practical reason:

The task of [practical] reasoning, then, is not to disprove some radically opposed first premise (say, killing people is no problem), but rather to show how the policy is unconscionable on premises which both sides accept, and cannot but accept. ... [I]ts job is to show up special pleas.

On this model ... practical argument starts off on the basis that my opponent shares at least some of the fundamental dispositions toward good and right which guide me. The error comes from confusion, unclarity, or unwillingness to face some of what he [sic] can't lucidly repudiate; and reasoning aims to show up this error. (1995, p. 36)

In the case of the back-to-basics movement, the job of reason is to show how its associated policies can only further damage the prospects of the disadvantaged; in the case of the Nazis, it is to show that their theories of racial superiority and perception of the Jewish threat are preposterous. (This is reason's job; whether it will win the day in either of these cases is another question.)

This conception. of practical reason dovetails with the broader interpretivist epistemology of social research and not only because they are both anti-foundationalist. Interpretivists hold, contra positivism, that just as social science is irremediably theory-laden, it is irremediably valueladen as well. Social scientific reasoning is value-laden-cuminterpretive-cum-constructivist and is thus shot through and through with practical reasoning. In this way, the ad hominem strategy generalizes to social research-and to education and to life-as a whole. Transformationists employ it to argue that postmodernism's all-out attack on reason winds up nullifying all knowledge claims, including any advanced by postmodernists themselves. As Benjamin Barber (1992) puts it

Reason can be a smoke screen for interest, but the argument that it is a smoke screen itself depends on reasonor we are caught up in an endless regression in which each argument exposing the dependency of someone else's argument on arbitrariness and self-interest is in turn shown to be self-interested and arbitrary (p. 109)

It is beyond the scope is this article to more fully develop this line of argument. Generally speaking, ad hominem challenges such as the one exemplified by Barber are frequently employed against postmodernists to show that they cannot consistently disavow reason. This is an especially damaging form of criticism when applied to educational theorists who would claim allegiance to postmod- 
ernism. Why this is so will become clear as my arguments further unfold.

\section{The Ontology of the Self}

Ontology is that part of philosophy that concerns itself with the kinds of entities that exist and the features they possess. For example, do numbers exist? In what sense? Where can we find them? How about social structures? Do selves exist? What features, if any, do different selves share? How are selves formed? Are selves relatively stable or always in flux?

In the previous section, I described interpretivists as embracing a constructivist conception of knowledge. This feature of interpretivism renders the philosophical distinction between epistemology and ontology considerably more artificial than my way of dividing this article may suggest (see Taylor, 1987). How human beings know and are known, and what knowledge consists in, is inextricably bound up with the kinds of things human beings are. And there is a further complication. Because human beings actively construct their social reality, the kinds of things human beings are is not necessarily the kinds of things they must or ought to be. Thus, distinguishing the moral-political from the ontological is also artificial.

Be they postmodernists or transformationists, interpretivists are like-minded in their rejection of the positivistinspired behaviorist conception of human nature in which human beings are portrayed as passive recipients of stimuli, explicable in terms of conditioning by exogenous causes. (For a comprehensive and lucid account of how positivism was cashed out in social research, see MacKenzie, 1977.) Interpretivists hold that human beings are selfcreating or, as Brian Fay (1987) puts it, activist in their behavior. That is to say, it is not as if human beings are simply pushed to and fro by. existing social arrangements and cultural norms. Instead, they actively shape and reshape these constraints on behavior. But there is a problem, and it parallels the one discussed earlier in connection with the nature of knowledge. Are human beings completely active? Is positivist-behaviorist characterization of them totally erroneous?

Insofar as postmodernists seek to deconstruct the workings of social structures and transformationists seek to undistort communication, each presupposes that human beings are not altogether active, that they can indeed be unwittingly pushed to and fro by unseen and unknown causes. Furthermore, because human nature is so malleable, the passive, positivistic-behavioristic conception of human nature can function as a self-fulfilling prophecy. As Dewey (1938) observes in this connection, after years of receiving and then regurgitating information presented by their teachers, school children will develop the habit of expecting (and demanding) that they play this passive role in learning. That is, they will be conditioned to fit the positivistbehaviorist conception of human nature.

So what is wrong with the positivist-behaviorist conception? Nothing. Nothing, that is, unless one is prepared to commit to the view that this conception ought not guide educational research and practice, that some version of the activist conception should. But let me set this observation aside for now in order to look into the controversy between postmodernists and transformationists about the ontology of self.
Postmodernists attribute to the traditional liberal and Marxist metanarratives a commitment to an essential human self, a fixed model of human nature, to which all humankind should aspire and in terms of which all should be measured-things like rational autonomy and species being, respectively. Postmodernists emphasize that, contrary to these essentialist conceptions, identities come in many forms, associated with race, class, and gender, among others. Identities must be seen as neither unified nor fixed, but as various and continually "displaced/replaced" (e.g., Lather, 1991). De-centering is the watchword: Placing the universal Everyman allegedly presupposed by Marxist and liberal metanarratives at the center can only function to normalize and terrorize the many Others on the margins.

On the transformationist view (and here I use John Searle, 1995, as my example ${ }^{2}$ ), maintaining that something is real does not entail maintaining that it cannot be constructed, much less that it must be essential and unchangeable. Automobiles, for example, would not be real if this were generally true. But consider money, the existence and nature of which is much less a "brute fact" than automobiles. Money is what Searle calls an "institutional fact"-a kind of fact that grows out of and would not exist but for human social arrangements and "collective intentionality." Nonetheless, money does not come into or go out of existence on the basis of what individual people believe or construct. For example, suppose someone owes me $\$ 1,000$. I cannot reject cash payment and demand gold because I happen to believe that currency is worth no more than the paper it is printed on. Whether I like it or not, currency is legal tender for the payment of debts.

The situation is parallel in the case of Searle's less formal "social facts." Take gender. To be sure, there have been and continue to be institutional facts associated with gender (e.g., exclusion from voting in the past and exclusion from certain forms of military duty today). But more far reaching are shared beliefs, expectations, know-how, and practices that make up the social facts of gender. In Western societies, the feminine gender historically has been identified with nurturing and preserving relationship on one hand and with a lack of worldliness and the capacity for abstract reasoning on the other. Women thus have been historically directed into activities such as homemaking, nursing, and elementary school teaching and away from engineering, politics, and science. Independent of what individual girls and women believe-and like it or not-there is a "gender regimen" (Connell, 1987) associated with a particular kind of feminine identity that is, in turn, associated with a large complex of social facts that shape it.

These social facts must be reckoned with in thinking about identity. Changing our being requires a good deal of time and effort, and there is no guarantee of success. Partly because of this, people often do not want to change and believe it is oppressive to expect them to. Instead, people want recognition of who they are (Taylor, 1994). And if this general observation about the phenomenology of the self were not true, it would be very difficult to make any sense whatsoever out of the demands to recognize diversity so prominent on the current political and educational scenes.

As the preceding paragraph suggests, there is no way to completely separate moral-political commitments from a conception of human nature. This echoes for a second time my remarks at the beginning of this section, and I will de- 
velop the implications in greater detail later. Here I as far as possible bracket the moral-political in order to look still further into the controversy between postmodernists and transformationists about the ontology of the self.

Searle (1995) employs the concept of "background of intentionality" to describe the peculiar context of human behavior and development. Against both mentalism (all human behavior is explicable in terms of conscious or unconscious understanding and intent) and behaviorism (all human behavior is explicable in terms of physical movements), Searle maintains that human beings simply have the capacity to gain the know-how required to respond to shared social and institutional facts in accordance with normative expectations, largely in virtue of their linguistic capacity to manage symbols.

Within this general framework, Searle develops the following general schema to explicate the ontological status of social facts: "X counts as $Y$ in $C$ " (p. 28). To again take Searle's favorite example, money, the U.S. dollar bill (X) counts as legal tender (Y) in the U.S. (C). One of Searle's fundamental points is that unlike gold, for example, there is nothing about the physical features of a dollar bill that gives rise to its value and the normatively sanctioned behaviors that surround it. Rather, its value, its counting as legal tender, is a result of "collective intentionality."

Gender, race, and a whole host of other social categories can be viewed on a similar model, though it might be more suggestively formulated as $X$ marks $Y$ in $C$. Race and gender $(\mathrm{Xs})$ each serve to mark a constellation of normatively sanctioned behaviors $(\mathrm{Y})$ associated with various contexts (Cs), including the context of schools. (Here I remind the reader that I am bracketing the issue of whether the norms in question are good. Norms need not be morally sanctioned to regulate human behavior.) In this way, although social categories (Xs) have no essence independent of what humans have constructed, they, like money, are no less real for that.

Gaining the know-how associated with collective intentionality and learning how to negotiate the social terrain is a long and complex task. And because identity formation is dialogical, as Charles Taylor says (1994), individuals unavoidably incorporate into their identities the normative structure associated with social categories and practices. Through many different dialogues in many different contexts, people learn what it is to be a man, a women, to be gay or lesbian, or to be an African American high school student.

Postmodernists who suggest that identities are constantly "displaced/replaced" (e.g., Lather, 1991) must concede that selves have to remain in place at least long enough to be the object of deconstruction. In the case of women, for instance, they may sometimes celebrate the traditional feminine identity they have formed, as in gynocentric feminism (Young, 1990), and may sometimes lament it, as in feeling like "a fraud" (Ornstein, 1995). Some similar form of ambivalence-coming out versus remaining closeted, being oppositional versus "acting White," for example-is characteristic of all marginalized groups. And this phenomenon, like the demand for recognition, makes sense only if human identities are relatively stable.

It should be observed that the general characterization of the ontology of the self provided by thinkers like Searle and Taylor is not one with which postmodernists necessarily disagree. The general idea that identity formation is dialog- ical is not one that postmodernists would find problematic. Furthermore, identity can be stable and, indeed, real. As Foucault (1979) says

It would be wrong to say the soul is an illusion, or an ideological effect. On the contrary, it exists, it has reality, it is produced permanently, around, on, within the body by the functioning of a power that is exercised ... on those one supervises, trains and corrects, over madmen, children at home and in school... . This is the historical reality of [the] soul, which, unlike the soul represented by Christian theology, is not born in sin and subject to punishment, but is born rather out of methods of punishment, supervision and constraint. (p. 29)

This leaves the controversy about the self between postmodernists and transformationists quite unsettled. Both are constructivists with respect to the ontology of the self: They agree that it is contingently formed through social interaction and that it has no transcendent essence. Then how do postmodernists and transformationists differ with respect to the self? The passage from Foucault points in the direction of an answer. For him (and postmodernists in general, I think) one must be ever wary of the normalizing and sinister influences that social forces have on the formation of selves (souls) and be constantly at the ready to expose, deconstruct, and throw them off. For tranformationists, not all normalizing forces are bad. They are, as it were, resting places for the self-and good ones, ones that education ought to promote.

The lesson here is that the ontology of the self cannot be viewed in the abstract. As I observed several times before, it is thoroughly entangled with epistemology. As the last several paragraphs show, it is also thoroughly entangled with what (if anything) is adopted as the moral-political mission of education, and it is here where the differences between postmodernists and transformationists are perhaps most perspicuous.

\section{Politics}

Neither transformationists nor postmodernists believe present social arrangements are just and democratic, and both seek to identify social structures and norms that serve to oppress people. Each, then, embraces deconstruction in this sense. What divides them is the reason for engaging in deconstruction and what comes after it.

In the extreme, the activity of deconstruction serves merely to challenge and disrupt the status quo. The question of what comes after it, of how social arrangements ought to be transformed so as to better approximate social justice is dismissed if not greeted with outright hostility. For this is the modernist project, which presupposes norms of rationality and morality around which to forge consensus. But such norms are totally ungrounded and, worse, when promoted by the powers that be, are also inherently oppressive (Ellsworth, 1992; Lyotard, 1987).

Catharine MacKinnon (1989) likens this brand of deconstruction to a "neo-Cartesian mind game" (p. 137) that goes nowhere politically, if not backwards. For it "raises acontextualized interpretive possibilities that have no real social meaning or real possibility of any, thus dissolving the ability to criticize the oppressiveness of actual meanings without making space for new ones" (1989, p. 137). Like DesCartes, this kind of deconstruction embraces hyperskep- 
ticism (Barber, 1992) as its starting point, but unlike DesCartes, it finds no "clear and distinct" moorings for knowledge. Indeed, it finds no moorings at all.

Transformationists (among whom I include MacKinnon and Barber) charge that insofar as the aim of this kind of deconstruction embraces the political goal of eradicating oppression, it undermines its own political project. ${ }^{3}$ This kind of deconstructivist activity renders unanswerable (if not unaskable) the question of who the terrorized Others on the margins might be. The reality of these Others as Others evaporates under the hot lights of deconstruction.

Transformationists concede that identities aren't rigidly fixed and that prescribing a particular voice for members of marginalized groups can be condescending, stereotyping, and oppressive. As Henry Louis Gates remarks regarding the feeling he gets from his White colleagues in the academy: It is as if they were to provide him with a script and say, "Be oppositional-please. You look so cute when you're angry" (1992, p. 185). But Gates also warns against taking this observation too far. He writes:

Foucault says, and let's take him at his word, that the "homosexual" as life form was invented sometime in the 19th century. Now, if there's no such thing as a homosexual, then homophobia, at least as directed toward people rather than acts, loses its rationale. But you can't respond to the discrimination against gay people by saying, "I'm sorry, I don't exist; you've got the wrong guy" (1992, pp. 37-38).

Gates uses this example to identify a tension between what he calls "the imperatives of agency" and "the rhetoric of dismantlement" (1992, p. 38, what I have been calling deconstruction). One can conceive of homosexuality (or race or gender) as "only a sociopolitical category" (1992, p. 37) as Gates puts it. But consistent with my observations in the previous section, that does not mean that such social categories (constructions) do not exist or are not real in their effects. Acknowledging that members of social groups do not necessarily speak with one voice, acknowledging that identity is, as Cameron McCarthy (1993) puts.it, nonsynchronous, transformationists are on their guard to avoid sliding into the sort of radical desconstruction of group identity Gates warns against in which all that remains are de-centered, radically unstable individuals.

The flip side of the transformationists' worry about the inability of radical deconstruction to make sense out of oppression is its inability to provide any guidance regarding how to educate persons so that they will be moral agents who can, among other things, recognize oppression and work against it. Daniel Dennett (1991), who rejects the Cartesian-or modernist-conception of the self in favor of a postmodernist conception, acknowledges the moralpolitical dangers in doing so. He thus embraces the idea of getting beyond a merely deconstructive activity to the activity of shaping selves of the right kind. Responding to an imagined interlocutor, Dennett writes:

I think I know what you're getting at. If a self isn't a real. thing, what happens to moral responsibility? One of the most important roles of self in our traditional conceptual schemes is as the place where the buck stops, as Harry Truman's sign announced. If selves aren't real-aren't really real-won't the buck just get passed on and on, round and round, forever? ... The task of constructing a self that can take responsibility is a major social and educational project. (pp. 429-430)

Nick Burbules (1996) makes a point similar to Dennett's when he observes that education is inherently about growth and development and is therefore inherently goal directed. If Dennett and Burbules are right (and one could invoke Dewey and his notion of growth, as well), it follows that however cautious educators can and ought to be about the norms, dispositions, attitudes, and knowledge they foster, foster some they must. In short, educators and educational researchers alike are required to engage in a constructive political activity.

Perhaps acknowledgment of this point explains why postmodernists in education are, by comparison to postmodernists more generally, relatively unabashed about embracing the project of ending oppression (but see Usher \& Edwards, 1994). In any case, postmodern educationists are unable to consistently confine themselves only to deconstruction, and whatever their avowals, they opt for transformation in the end.

Consider the following remark by Elisabeth Ellsworth:

[I]n a classroom in which "empowerment" is made dependent on rationalism, those perspectives that would question the political interests (sexism, racism, colonialism, for example) expressed and guaranteed by rationalism would be rejected as "irrational" (biased, partial). (1992, p. 98)

But what is the alternative to rationalism? Benjamin Barber asks:

How can ... reformers think they will empower the voiceless by proving that voice is always a function of power? ... How do they think the struggle for equality and justice can be waged with an epistemology that denies standing to reasons and normative rational terms? (1992, p. 123)

Barber adds: "The powerful toy with reason, the powerless need it, for by definition it is their only weapon" (p. 124).

It would seem there is no way for those who would reject rationalism carte blanche to adequately respond to Barber's challenge. In the end, some overarching (and presumably modernist) principle or principles must be embraced (Burbules \& Rice, 1991). And Ellsworth does exactly this when she proffers the following question as the "final arbiter" for determining the acceptability of anti-racist actions:

To what extent do our political strategies and alternative narratives about social difference succeed in alleviating campus racism, while at the same time managing not to undercut the efforts of other social groups to win selfdefinition? (1992, p. 110)

Isn't this a principle guiding political action? Doesn't it have a specific goal? Isn't it (shouldn't it be, can't it be) rationally agreed to?

Some self-described postmodernist educationists explicitly embrace general political principles. For example, Stanley Aronowitz and Henry Giroux (1991) acknowledge the force of the general sort of criticism advanced by Barber. In response, they call for a critical (versus apolitical) postmodernism in which the "postmodern politics of difference" is combined with the "modernist struggle for justice, equality, and freedom" (p. 194). 
Here we see the line (or border) between postmodernists and transformationists explicitly crossed. For critical postmodernism cannot be systematically distinguished from the so-called metanarratives of Marxism and liberalism that it putatively rejects. The modernist struggle continues for Marxism and liberalism, and neither tradition has remained static. On the contrary, both have evolved so as to better cope with the politics of difference, so emphasized in postmodernist analyses. ${ }^{4}$

As I acknowledged at the outset, there are dangers in trying to divide philosophical stances taken toward the interpretive turn into postmodernist and transformationist. This should be even more evident in light of the preceding several paragraphs. In educational theory at least, various views seem to fall on a continuum regarding the degree to which they embrace transformation. Very few shun transformation altogether.

Those I have been calling postmodernists tread very lightly. They are highly tentative about speaking for others and categorizing them and about what to do in the wake of deconstruction, and are highly suspicious of those who claim to know what is best. They also emphasize paying very close attention to one's own social position and subjectivities. Those I have been calling transformationists do not ignore these concerns, but they are less guarded. They proceed by identifying oppressed groups and by articulating and employing broad political principles-justice, equality, and the like-to criticize existing conditions and to suggest the direction that transformations should take.

Ellsworth, as well as Aronowitz and Giroux, emphasizes curriculum, pedagogy, and politics, but the same point can be made with respect to educational research. Consider Patti Lather's book Getting Smart (1991). The subtitle, Feminist Research and Pedagogy With/in Postmodernism, as well as much of her exposition and vocabulary, suggests she is advancing a straightforward postmodernist approach to educational research, to be distinguished from a modernist (or Enlightenment) one. But Lather explicitly denies that she embraces thoroughgoing deconstructionism (and its nihilistic consequences); she would limit deconstruction to opening up space for the expression of hitherto silenced voices. In this connection, she repeatedly and approvingly cites the work of critical theorist Brian Fay (1976, 1987), whose project is clearly a transformational one (however guarded and qualified).

In general, interpretive educational research jettisons the positivist goal of "technical control" (Howe, 1992). Various ends (academic achievement and increased economic competitiveness, for instance) cannot be bracketed and set to one side while educational researchers go about the task of investigating the best means with an eye toward exerting more effective control. Ends must be left on the table, as not ultimately separable from means, and as themselves being an important part of what needs to be investigated and negotiated. Postmodernists and transformationists are in substantial agreement on this point. They diverge from here, however, and their respective responses to the demise of the positivist fact/value distinction may be used to illustrate how.

The fact/value distinction is shorthand for a much more inclusive set of distinctions. On the fact side, it also puts rationality, science, means, cognition, objectivity, and truth. On the value side, it also puts irrationality, politics, ends, interests, subjectivity, and power. Postmodernists focus on the value side and collapse the fact side into it. Thus, we get the picture (in Foucault, for instance) that science, truth, and the like are simply masks for power. Alternatively, transformationists blend the fact and value sides. Thus, we get the picture (in Habermas, for instance) that al though science and truth can be corrupted-distorted-by power, they are nonetheless redeemable if checked by the kind of rationality associated with an emancipatory interest.

But here again the difference between postmodernists and transformationists (at least in education) may be overdrawn. Assume that postmodernists do, indeed, embrace the goal of ending oppression. This puts them in some general agreement with transformationists. Nonetheless, they may still complain that transformationists are far too confident both in how they understand this goal and the means by which it can be best achieved. It is they-the transformationists-who embrace an oppressive project because it is overconfident and paternalistic.

In my view, this sort of disagreement can but does not have to turn on fundamental philosophical incompatibilies. It may turn on practical questions like, When should I bite my tongue? What's the best way to move things along? What would be the long-term consequences of intervening now? How can I get these people to see what's really going on here? And other questions like, What's my stake in this? Have I failed to appreciate what's being said? Who am I to interpret this situation by my lights? And so on. Consider these questions in light of the practice of female circumcision. Now, consider them in light of what we know about public schools' treatment of girls, people of color, and gay, lesbian, and bisexual youth. I am suggesting that whether they have done so or not, postmodernists and transformationists could end up answering these questions in much the same way. They could end up agreeing that taking action in a certain set of circumstances would be ill-advised; they could end up agreeing that action should be taken but in the form of some tentative first steps and so forth. If postmodernists embrace the view (and I'm not sure any do) that it is not just bad from a practical perspective to act on certain value judgments-about what is good, bad, oppressive, should be changed-in certain circumstances but that such judgments can (ought to?) never be rendered, then their view is morally and politically untenable. Worse, it is dangerous.

\section{Conclusion}

In the wake of the interpretive turn, the philosophical debate is now between those who seek some new understandings of knowledge, rationality, truth, and objectivity (i.e., transformationists) and those who seem ready to abandon these as hopelessly wedded to the bankrupt modernist project (i.e., postmodernists).

But this may well draw the line too sharply. The specific disagreements between postmodernists and transformationists-on epistemology, ontology, and politicsmay be largely practical. In any case, there seem to be three general points of agreement. First, subjectivities count. This is a general implication of the interpretive turn and the constructivist epistemology that goes with it. Second, social arrangements are irremediably interest-, power-, and value-laden. Accordingly, they need to be carefully examined-deconstructed-in this light. And third, the end result of educational research and practice 
should be transformation to a more just and democratic system of schooling and, ultimately, a more just and democratic society.

To be sure, differences between postmodernists and transformationists are significant. But if I am right, interpretivists of all stripes embrace both deconstruction and transformation. They would do well to avoid overblowing their differences on how to understand and balance these in a way that engenders a new generation of paradigm cliques. ${ }^{5}$

\section{Notes}

This article liberally borrows from my chapter titled "Qualitative Educational Research: The Philosophical Issues" in the forthcoming fourth edition of the Handbook of Research on Teaching, edited by Virginia Richardson. It also borrows a few sentences and paragraphs from Howe (1997, chapter 4).

1 Some feminists are postmodernists, but many belong in the transformationist camp-for example, Seyla Benhabib, Iris Marion Young Catharine MacKinnon, Lorraine Code, Sandra Harding, and Nancy Frazer, to name a few.

2 Although I find much of Searle's analysis useful, I do not embrace his realist view and believe his views on social reality do not depend on it.

${ }^{3}$ For an elaboration of this argument, see also Benhabib, 1995; Bernstein, 1996; Gutmann, 1994; Lyon, 1994; Taylor, 1994.

- Numerous examples exist in political theory, but for specific applications of critical theory to education, see Robert Young (1990) and Nicholas Burbules (1993). For an application of liberalism, see Kenneth Howe (1997).

5 This a description I once used to characterize the quantitative/ qualitative debate (Howe, 1988).

\section{References}

Aronowitz, S., \& Giroux, H. (1991). Postmodern education. Minneapolis: University of Minnesota Press.

Barber, B. (1992). An aristocracy of everyone. New York: Ballantine Books.

Beck, C. (1994). Postmodernism, pedagogy, and the philosophy of education. In A. Thompson (Ed.), Philosophy of education 1993 (pp. 1-13). Urbana, IL: Philosophy of Education Society.

Benhabib, S. (1995). Feminism and postmodernism. In L. Nicholson (Ed.), Feminist contentions (pp. 17-34). New York: Routledge.

Bernstein, R. (1996, April). Pragmatism and postmodernism: The relevance of John Dewey. Paper presented at the meeting of the American Educational Research Association, New York.

Burbules, N. (1993). Dialogue in teaching. New York: Teachers College Press.

Burbules, N. (1996). Postmodern doubt and philosophy of education. In A. Neiman (Ed.), Philosophy of education 1995 (pp. 39-48). Urbana, IL: Philosophy of Education Society.

Burbules, N., \& Rice, S. (1991). Dialogue across difference: Continuing the conversation. Harvard Educational Review, 61(4), 393-416.

Connell, R. W. (1987). Gender and power. Stanford, CA: Stanford University Press.

Dennett, D. (1991). Consciousness explained. New York: Little, Brown and Company.

Dewey, J. (1938). Experience and education. New York: Macmillan Publishing Company

Doll, W. (1993). A post-modern perspective on curriculum. New York: Teachers College Press.

Ellsworth, E. (1992). Why doesn't this feel empowering? In C. Luke \& J. Gore (Eds.), Feminisms and critical pedagogy (pp. 90-119). New York: Routledge.
Fay, B. (1976). Social theory and political practice. London: Unwin Hyman.

Fay, B. (1987). Critical social science. Ithaca, NY: Cornell University Press.

Foucault, M. (1979). Discipline and punish: The birth of the prison. New York: Vintage Books.

Foucault, M. (1987). Questions of method: An interview with Michel Foucault. In K. Baynes, J. Bohman, \& T. McCarthy (Eds.), After philosophy: End or transformation? (pp. 100-117). Cambridge, MA: MIT Press.

Frazer, N. (1995). Pragmatism, feminism and the linguistic turn. In L. Nicholson (Ed.), Feminist contentions (pp. 157-171). New York: Routledge.

Gates, H. L. (1992). Loose canons. New York: Oxford University Press.

Gutmann, A. (1994). Introduction. In A. Gutmann (Ed.), Multiculturalism: Examining the politics of recognition (Pp. 3-24). Princeton, NJ: Princeton University Press.

Howe, K. R. (1988). Against the quantitative-qualitative incompatibility thesis (or dogmas die hard). Educational Researcher, 17(8), 10-16.

Howe, K. R. (1992). Getting over the quantitative-qualitative debate. American Journal of Education, 100(2), 236-256.

Howe, K. R. (1997). Understanding equal educational opportunity: Social justice, democracy, and schooling. New York: Teachers College Press.

Howe, K. R., \& Eisenhart, M. A. (1990). Standards for qualitative (and quantitative) research: A prologomenon. Educational Researcher, 19(4), 2-9.

Kuhn, T. (1970). The structure of scientific revolutions. Chicago: University of Chicago Press.

Kuhn, T. (1977). The essential tension: Selected studies in scientific tradition and change. Chicago: University of Chicago Press.

Lather, P. (1991). Getting smart: Feminist research and pedagogy with/in postmodernism. New York: Routledge.

Lyon, D. (1994). Postmodernity. Minneapolis: University of Minnesota Press.

Lyotard, J. (1987). The postmodern condition. In K. Baynes, J. Bohman, \& T. McCarthy (Eds.), After philosophy: End or transformation? (pp. 67-94). Cambridge, MA: MIT Press.

MacKenzie, B. (1977). Behaviorism and the limits of scientific method. Atlantic Highlands, NJ: Humanities Press.

MacKinnon, C. (1989). Toward a feminist theory of the state. Cambridge, MA: Harvard University Press.

McCarthy, C. (1993). Beyond the poverty in race relations Nonsynchrony and social difference in education. In L. Weis \& $\mathrm{M}$. Fine (Eds.), Beyond silenced voices (pp. 325-346). New York: State University of New York Press.

Ornstein, P. (1995). Schoolgirls. New York: Anchor Books.

Rabinow, P., \& Sullivan, W. (1979). The interpretive turn: Emergence of an approach. In P. Rabinow \& W. Sullivan (Eds.), Interpretive social science (pp. 1-21). Los Angeles: University of California Press.

Searle, J. (1995). The construction of social reality. New York: Free Press.

Smith, J. K., \& Heshusius, L. (1986). Closing down the conversation: The end of the quantitative-qualitative debate among educational researchers. Educational Researcher, 15(1), 4-12.

Taylor, C. (1987). Interpretation and the sciences of man. In P. Rabinow \& W. Sullivan (Eds.), Interpretive social science: $A$ second look (pp. 33-81). Los Angeles: University of California Press.

Taylor, C. (1991). The ethics of authenticity. Cambridge, MA: Harvard University Press.

Taylor, C. (1994). The politics of recognition. In A. Gutmann (Ed.), Multiculturalism: Examining the politics of recognition (pp. 25-74). Princeton, NJ: Princeton University Press.

Taylor, C. (1995). Philosophical arguments. Cambridge MA: Harvard University Press.

Usher, R., \& Edwards, R. (1994). Postmodernism and education. New York: Routledge.

Walzer, M. (1983). Spheres of justice. New York: Basic Books.

Young, I. M. (1990). Humanism, gynocentrism, and feminist politics. In Throwing like a girl and other essays in philosophy and social theory (pp. 73-91). Bloomington: Indiana University Press.

Manuscript received March 31, 1997 Revision received December 15, 1997 Accepted January 5, 1998 